\title{
Antibiotic Susceptibility Profiles of Listeria monocytogenes Strains Isolated from Food Products and Clinical Samples
}

\section{Profiluri de rezistență ale unor tulpini de Listeria monocytogenes izolate din probe clinice și produse alimentare}

\author{
Marius Eduard Caplan ${ }^{1}$ Lorena Andreea Mateescu², Tatiana Vassu Dimov², \\ Alexandru Rafila ${ }^{3}$, Alina Maria Borcan ${ }^{3}$ \\ 1. University of Agronomic Sciences and Veterinary Medicine Bucharest, \\ Faculty of Veterinary Medicine \\ 2. University of Bucharest, Faculty of Biology, Bucharest, Romania \\ 3. University of Medicine and Pharmacy "Carol Davila" Bucharest, Romania
}

\begin{abstract}
Listeria monocytogenes has a ubiquitous distribution in nature and could contaminate food of animal origin, causing severe infections in humans. Till present, little is known about the antibiotic resistance profiles of these strains in Romania. The aim of this study was to determine the antibiotic susceptibility patterns of 37 L. monocytogenes strains isolated from animal derived foods and from clinical samples. Food samples were collected from meat and dairy products, between 2009 and 2013. Clinical samples were collected from patients with septicemia, meningitis/meningo-encephalitis, abortion cases and newborns, hospitalized during April 2010 - April 2013 in three medical institutions from Bucharest: Babes Hospital, Elias Hospital, National Institute of Infectious Diseases (INBI) Matei Bals. All tested isolates exhibited resistance to cephalosporins and nalidixic acid; one strain isolated from boiled shell snails was resistant to trimethoprim/sulfamethoxazole. The resistance to the first choice antibiotic ampicillin in L. monocytogenes strains isolated from severe infections is underlining the need of in vitro antibiotic susceptibility testing of each clinical isolate to establish the efficacy of different antibiotics, as well as of extended epidemiological studies to highlight the resistance profiles of L. monocytogenes strains circulating in our country.
\end{abstract}

Key words: Listeria monocytogenes, food, invasive infections, antibiotics, resistance

\section{Rezumat}

Listeria monocytogenes are o distribuţie ubiquitară în natură şi poate contamina produsele alimentare de origine animală, provocând infecții severe la om. Până în prezent există foarte puține date cu privire la profilurile de rezistenţă ale tulpinilor circulante în România. Scopul acestui studiu a fost determinarea pattern-urilor de rezistență la antibiotice ale unor tulpini de L. monocytogenes $(n=37)$ izolate din produse alimentare de origine animală şi din probe clinice. Probele din alimente (carne şi produse lactate), au fost colectate în perioada 2009-

*Corresponding author: Lorena Andreea Mateescu, University of Bucharest, Faculty of Biology, Bucharest, Romania, phone: +40213181576, e-mail: mlorenaandreea@yahoo.com 
2013. Probele clinice au fost recoltate de la pacienţi cu septicemie, meningită/meningo-encefalită, cazuri de avort spontan şi nou-născuţi, spitalizaţi în perioada Aprilie 2010 - Aprilie 2013 în trei Instituţii Medicale din Bucureşti: Spitalul Elias, Spitalul Victor Babes si Institutul Naţional de Boli Infecţioase (INBI) Matei Bals. Toate tulpinile testate au prezentat rezistenţă la cefalosporine şi acidul nalidixic; o tulpină izolată din melci fierţi a fost rezistentă la Trimetoprim/sulfametoxazol. Rezistenţa unora dintre tulpinile analizate la ampicilina, antibiotic de elecţie pentru terapia infecţiilor cauzate de L. monocytogenes, subliniază necesitatea testării in vitro a sensibilitatii la antibiotice a fiecarui izolat clinic pentru a stabili eficienţa diferitelor antibiotice, precum şi a unor studii epidemiologice extinse în scopul stabilirii profilurilor de rezistenţă ale tulpinilor de L. monocytogenes circulante în ţara noastră.

Cuvinte cheie: Listeria monocytogenes, alimente, infecții invazive, antibiotice, rezistență

Received: 22 ${ }^{\text {nd }}$ August 2013; Accepted: $2^{\text {nd }}$ April 2014; Published: $2^{\text {nd }}$ May 2014.

\section{Introduction}

Listeria monocytogenes is the main pathogenic species of the respective genus, found both in humans and animals $(1,2)$. L. monocytogenes is a Gram-positive rod, capable of growing in conditions such as low temperature, acidic $\mathrm{pH}$, high salt concentration, resistant to the procedures applied in the food industry to inactivate pathogenic microorganisms $(3,4)$.

L. monocytogenes is often implicated in human listeriosis, a severe disease which can determine septicemia, meningitis/meningo-encephalitis, abortion and baby illness at birth (5). Susceptible population groups include the elderly people, immunocompromised individuals, pregnant women and their fetuses or neonates (1). Consumption of food products contaminated with this microorganism is the main cause of human listeriosis.

Antimicrobial drugs are used routinely to treat listeriosis in humans and animals. For the therapy of listeriosis, the first choice antibiotic treatment is represented by ampicillin or a combination of ampicillin with an aminoglycoside such as gentamycin or streptomycin (6). In the last years, some studies have reported $L$. monocytogenes strains that showed multiple drug resistance to different antimicrobial substances, with significance for the public health, therefore requiring a rigorous monitoring of the antimicrobial susceptibility of L. monocytogenes strains (7 -9).
The present study evaluates the susceptibility profiles of $37 \mathrm{~L}$. monocytogenes strains, isolated from animal food products and clinical human samples in Romania, to 15 antibiotics used for the treatment of human and animal bacterial infections.

\section{Materials and methods}

\section{Bacterial strains}

Out of the total number of $37 \mathrm{~L}$. monocytogenes tested strains, 19 were collected between 2009 and 2013 from various meat and dairy products, including raw minced meat $(n=4)$, pork muscular tissue $(n=1)$, beef muscular tissue $(n=1)$, sausages $(n=5)$, smoked bacon $(n=2)$, bacon in processing $(\mathrm{n}=1)$, poultry carcass $(\mathrm{n}=1)$, chicken frankfurters $(\mathrm{n}=1)$, boiled shell snails $(\mathrm{n}=1)$ and cheese products $(\mathrm{n}=2)$. The rest of 18 monocytogenes strains were isolated from clinical samples, represented by blood culture $(\mathrm{n}=7)$ and cerebrospinal fluid $(\mathrm{n}=11)$, from patients with septicemia, meningitis/meningo-encephalitis, abortion and newborns, hospitalized from April 2010 to April 2013 in three medical institutions in Bucharest: Babes Hospital, Elias Hospital, National Institute of Infectious Diseases (INBI) Matei Bals (containing two isolate-pairs, i.e. blood-culture and cerebrospinal fluid, from two patients with sepsis and meningitis/meningo-encephalitis), respecting the ethical issues concerning studies involving human samples. 
These samples were processed according to SR EN ISO 11290 standards part 1 and part 2, (10-12), and colonies grown on PALCAM agar were identified as L. monocytogenes. The identification of $L$. monocytogenes was performed in INBI "Matei Bals" and the confirmation was performed by the National Reference Center for Zoonotic Infections in National Institute for Research and Development in Microbiology and Immunology (NIRDMI)-Cantacuzino. Additionally, L. monocytogenes ATCC 19111 type 1 was used as reference strain. The L. monocytogenes isolates were stored at $-80^{\circ} \mathrm{C}$ in Brain Heart Infusion (BHI) broth (Oxoid) containing 20\% (v/v) glycerol. Before use, the pathogenic strains of $L$. monocytogenes were activated in $\mathrm{BHI}$ at $37^{\circ} \mathrm{C}$ for $24 \mathrm{hrs}$.

\section{Antimicrobial susceptibility testing}

The disk diffusion method was used in order to assess the resistance profiles of both the clinical and the food-borne L. monocytogenes strains. The susceptibility testing was performed using a number of 15 antibiotics (Oxoid), with the following concentrations: 10U Penicillin,

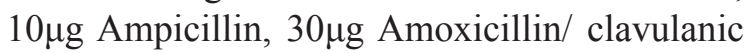
acid, $10 \mu \mathrm{g}$ Imipenem, 30 $\mu \mathrm{g}$ Cefuroxime, $30 \mu \mathrm{g}$ Amikacin, $10 \mu \mathrm{g}$ Gentamicin, 30 $\mu \mathrm{g}$ Neomycin, $30 \mu \mathrm{g}$ Nalidixic acid, $5 \mu \mathrm{g}$ Ciprofloxacin, 30 $\mu \mathrm{g}$

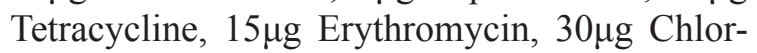
amphenicol, $30 \mu \mathrm{g}$ Rifampicin, $1.25 \mu \mathrm{g} / 23.75 \mu \mathrm{g}$ Trimethoprim/Sulfamethoxazole. The results were interpreted according to CLSI (Clinical and Laboratory Standards Institute), 2006 criteria. L. monocytogenes ATCC 19111 type 1 and Staphylococcus aureus ATCC 29213 were used as control strains. E-test strips (AB bioMérieux) were used in order to determine the MICs of different antibiotics in the case of a clinical $L$. monocytogenes strain that showed resistance to beta-lactam antibiotics (i.e. ampicillin, amoxicillin+clavulanic acid, imipenem). The strips containing different antibiotic exponential gradients (expressed in $\mu \mathrm{g}$ ), i.e. 0.002-32 Ciprofloxacin, 0.016-256 Clindamycin, 0.016-256 Erythromycin, 0.064-1024 Fosfomycin, 0.016-256 Gentamicin, 0.002-32 Imipenem, 0.016-256 Oxacillin, 0.016-256 Phenoxymethylpenicillin, 0.002-32 Rifampicin, 0.016-256 Teicoplanin, 0.016-256 Tetracycline, 0.016-256 Vancomycin.

\section{Results}

This paper reports the antibiotic susceptibility testing of 37 L. monocytogenes strains isolated from foodborne and clinical samples, identified using exclusively phenotypic tests, since molecular taxonomy is not yet implemented in the laboratories performing this study. Apart from penicillin, ampicillin and trimethoprim-sulfamethoxazole, for which clinical breakpoints for Listeria susceptibility testing are defined according to the Clinical and Laboratory Standard Institute (CLSI), in the present study CLSI criteria for staphylococci were used for the interpretation of antibiotic susceptibility results (13).

All L. monocytogenes food isolates were susceptible to the first choice antibiotic drugs, represented by penicillins (Table I). Concerning the antibiotic susceptibility spectrum, the food strains were fully susceptible to penicillin, ampicillin, amoxicillin+clavulanic acid, imipenem, amikacin, gentamicin, chloramphenicol, rifampicin, tetracycline. One of the 19 tested strains was resistant to trimethoprim/sulfamethoxazole. All tested strains proved to be resistant to nalidixic acid and cefuroxime. Six strains were intermediate resistant to ciprofloxacin, one to erythromycin and three to neomycin.

The clinical strains (Table II) proved to be susceptible to aminoglycosides, tetracyclines, chloramphenicol, rifampin and trimethoprim/ sulfamethoxazole. Nine strains proved to be intermediate resistant to ciprofloxacin and one to erythromycin. One isolate-pair (from the blood-culture and cerebrospinal fluid of an im- 
Table I. Antibiotic resistance/susceptibility spectrum of the food strains

\begin{tabular}{|c|c|c|c|c|c|}
\hline \multirow{2}{*}{\multicolumn{3}{|c|}{ Antibiotic /dose $(\mu \mathrm{g} / \mathrm{disc})$}} & \multicolumn{3}{|c|}{ L.monocytogenes strains } \\
\hline & & & $\mathbf{S}$ & $\vec{I}$ & $\mathbf{R}$ \\
\hline \multirow{5}{*}{ 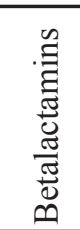 } & \multirow{3}{*}{ Penicillins } & Penicillin G 10U & 19 & & \\
\hline & & Ampicillin $10 \mu \mathrm{g}$ & 19 & & \\
\hline & & Amoxicillin + Clavulanic Ac $30 \mu \mathrm{g}$ & 19 & & \\
\hline & Cephalosporins & Cefuroxime $30 \mu \mathrm{g}$ & & & 19 \\
\hline & Penems & Imipenem $10 \mu \mathrm{g}$ & 19 & & \\
\hline \multirow{3}{*}{\multicolumn{2}{|c|}{ Aminoglycosides }} & Amikacin $30 \mu \mathrm{g}$ & 19 & & \\
\hline & & Gentamycin $10 \mu \mathrm{g}$ & 19 & & \\
\hline & & Neomycin $30 \mu \mathrm{g}$ & 16 & 3 & \\
\hline \multirow{2}{*}{\multicolumn{2}{|c|}{ Quinolones }} & Nalidixic Ac. $30 \mu \mathrm{g}$ & & & 19 \\
\hline & & Ciprofloxacin $5 \mu \mathrm{g}$ & 13 & 6 & \\
\hline \multicolumn{2}{|c|}{ Tetracyclines } & Tetracycline $30 \mu \mathrm{g}$ & 19 & & \\
\hline \multicolumn{2}{|c|}{ Macrolides } & Erythromycin $15 \mu \mathrm{g}$ & 18 & 1 & \\
\hline \multicolumn{2}{|c|}{ Phenicols } & Chloramphenicol $30 \mu \mathrm{g}$ & 19 & & \\
\hline \multirow{2}{*}{\multicolumn{2}{|c|}{ Other antibiotics }} & Rifampicin $30 \mu \mathrm{g}$ & 19 & & \\
\hline & & Sulphamethoxazole/Trimethoprim $1,25 \mu \mathrm{g} / 23,75 \mu \mathrm{g}$ & 18 & & 1 \\
\hline
\end{tabular}

munocompromised patient with sepsis and meningitis/meningo-encephalitis) proved to be resistant to beta-lactam antibiotics (oxacillin, ampicillin, amoxicillin+clavulanic acid and imipen- em) both in disk diffusion method and in E-test (Table III). Moreover, four strains were resistant to ciprofloxacin, from which one isolate-pair (blood-culture and cerebrospinal fluid) from a

Table II. Antibiotic resistance/susceptibility spectrum of the clinical strains

\begin{tabular}{|c|c|c|c|c|c|}
\hline \multirow{2}{*}{\multicolumn{2}{|c|}{ Antibiotic /dose $(\mu \mathrm{g} / \mathrm{disc}$}} & & \multicolumn{3}{|c|}{ L.monocytogenes strains } \\
\hline & & & $\mathbf{S}$ & I & $\mathbf{R}$ \\
\hline \multirow{5}{*}{ 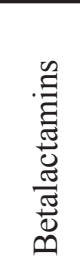 } & \multirow{3}{*}{ Penicillins } & Penicillin G $10 \mathrm{U}$ & 18 & & \\
\hline & & Ampicillin $10 \mu \mathrm{g}$ & 16 & & 2 \\
\hline & & Amoxicillin + Clavulanic Acid $30 \mu \mathrm{g}$ & 16 & & 2 \\
\hline & Cephalosporins & Cefuroxime $30 \mu \mathrm{g}$ & & & 18 \\
\hline & Penems & Imipenem $10 \mu \mathrm{g}$ & 16 & & 2 \\
\hline \multirow{3}{*}{\multicolumn{2}{|c|}{ Aminoglycosides }} & Amikacin $30 \mu \mathrm{g}$ & 18 & & \\
\hline & & Gentamycin $10 \mu \mathrm{g}$ & 18 & & \\
\hline & & Neomycin $30 \mu \mathrm{g}$ & 18 & & \\
\hline \multirow{2}{*}{\multicolumn{2}{|c|}{ Quinolones }} & Nalidixic Ac. $30 \mu \mathrm{g}$ & & & 18 \\
\hline & & Ciprofloxacin $5 \mu \mathrm{g}$ & 5 & 9 & 4 \\
\hline \multicolumn{2}{|c|}{ Tetracyclines } & Tetracycline $30 \mu \mathrm{g}$ & 18 & & \\
\hline \multicolumn{2}{|c|}{ Macrolides } & Erythromycin $15 \mu \mathrm{g}$ & 17 & 1 & \\
\hline \multicolumn{2}{|c|}{ Phenicols } & Chloramphenicol $30 \mu \mathrm{g}$ & 18 & & \\
\hline \multirow{2}{*}{\multicolumn{2}{|c|}{ Other antibiotics }} & Rifampicin $30 \mu \mathrm{g}$ & 18 & & \\
\hline & & Trimethoprim/Sulfamethoxazole $1.25 \mu \mathrm{g} / 23.75 \mu \mathrm{g}$ & 18 & & \\
\hline
\end{tabular}

$\mathrm{S}=$ susceptible; $\mathrm{I}=$ intermediary; $\mathrm{R}=$ resistant 
Table III. MIC levels to different antibiotics of penicillin resistant strain

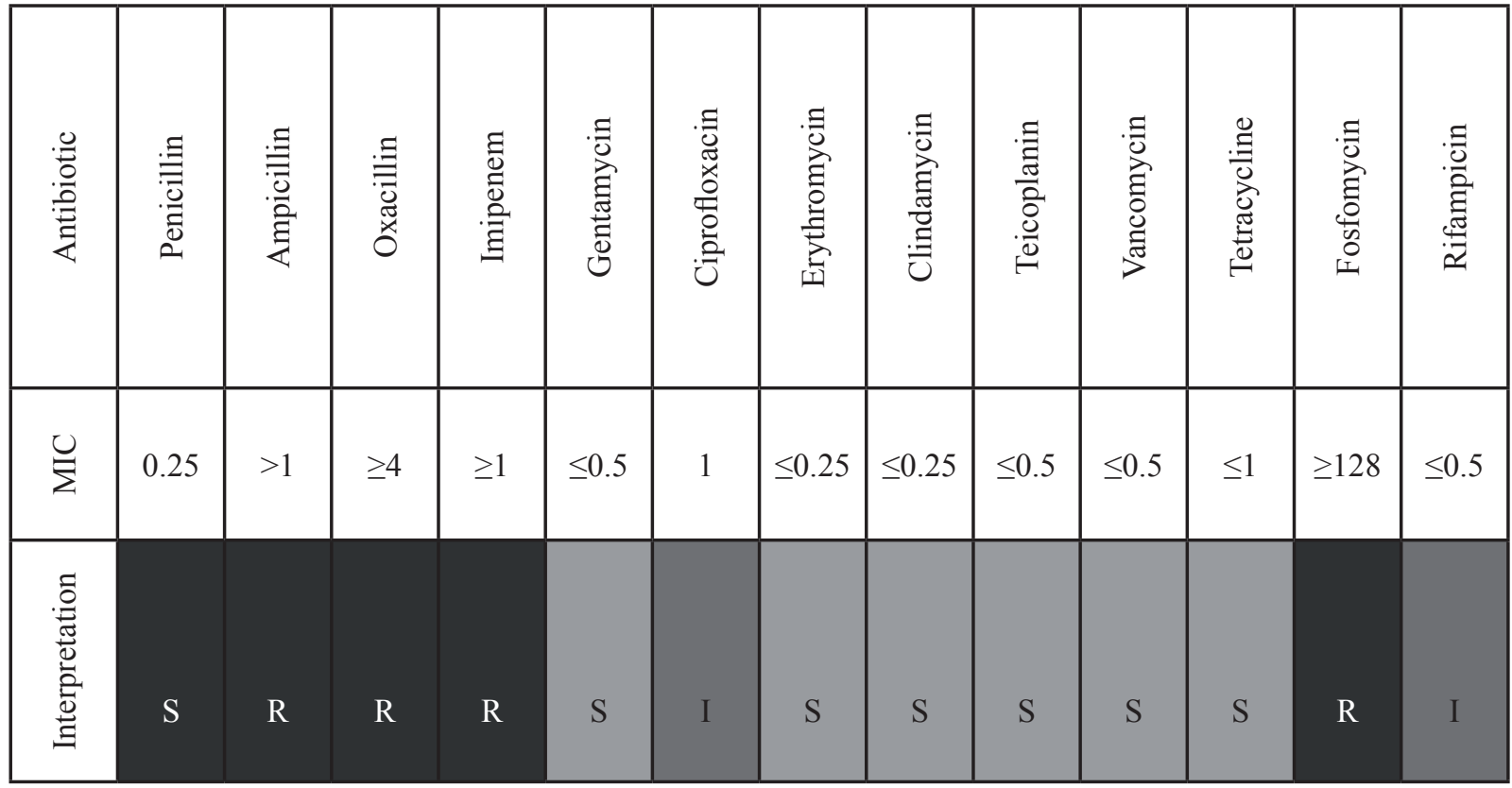

deceased woman with meningitis, and one from a patient with abortion in the $2 \frac{1}{2}$ month. All clinical strains were resistant to nalidixic acid and cefuroxime.

\section{Discussion}

Till present, little is known about the antibiotic resistance profiles of these strains in Romania. The present study, although performed on a small number of strains, is among the first reports on susceptibility profiles of food borne and clinical L. monocytogenes strains isolated in our country. The limited number of clinical strains can be explained by the fact that listeriosis is less common in Romania compared to other European countries, while food isolates of L. monocytogenes are usually unreported, thus making it difficult to gather a large collection of strains. Also, a recent study had shown that out of twenty five samples positive for L. monocytogenes by classical microbiological method, only 22 were confirmed by real-time PCR, suggesting that using only the standard method can lead to false results (14).

The standard antibiotic therapy for listeriosis is represented by penicillin or ampicillin with gentamicin. For the patients with allergy to penicillin, the treatment may use a combination of vancomycin with an aminoglycoside, as well as cotrimoxazole with rifampin $(6,15,17,18)$.

All tested L. monocytogenes strains proved to exhibit natural resistance phenotypes to the second and third generation cephalosporins and nalidixic acid, as mentioned by other literature data $(7,16,19)$. Our results are similar to those obtained by Ennaji et al, showing that almost all the analyzed strains (43 strains) of L. monocytogenes were susceptible to a wide range of antibiotics effective against Gram-positive bacteria, belonging to aminoglycosides group and glycopeptides, but were completely resistant to nalidixic acid, colistine, and second and third generations cephalosporins (19). For this reason, nalidixic acid is incorporated into selective media for the isolation of L. monocytogenes. The high 
level of innate resistance of L. monocytogenes to cephalosporins may be especially significant since members of this family of $\beta$-lactams are frequently used to treat sepsis of unknown etiology $(9,20)$.

The high rate of ciprofloxacin resistance and intermediate resistance among foodborne and clinical strains is a matter of concern, this trend being recently reported in other studies, particularly in food chain isolates of $L$. monocytogenes $1 / 2 \mathrm{a}$. It has been demonstrated that ciprofloxacin exposure could co-select resistance to other antimicrobial agents too (21).

The fact that $94.5 \%$ L. monocytogenes strains isolated from food products and clinical samples were susceptible to penicillins, the antibiotics commonly used for both veterinary and human listeriosis treatment, suggests that ampicillin or penicillin plus an aminoglycoside could remain the treatment of choice for listeriosis in Romanian patients. However, the fact that two L. monocytogenes strains, isolated from severe infections, showed resistance to different beta-lactam antibiotics, including ampicillin and amoxicillin+clavulanic acid is underlining the need of in vitro antibiotic susceptibility testing of each clinical isolate in order to establish the efficacy of different antibiotics, as well as of extended epidemiological studies to highlight the resistance profiles of $L$. monocytogenes strains circulating in our country. It has to be taken into account that, although the prevalence of acquired antibiotic resistance in Listeria isolates still remains low, the transferability of the resistance markers proven for Enterococcus faecalis recipient could facilitate further spread in the future. The high susceptibility rate to trimethoprim/sulfamethoxazole (97.2\%) indicates that this antibiotic could be used in association with rifampicin as a second-choice therapy in penicillin-allergic patients. The preserved susceptibility of foodborne, clinical, and environmental Listeria isolates to trimethoprim/sulfamethoxaz- ole was confirmed also in a recent, large scale studies, performed on a large number of strains $(22,23)$.

\section{Acknowledgements}

This work was partialy supported by the strategic grant POSDRU / ID 76888, Project "Doctoral program for training scientific researchers" co-financed by the European Social Found within the Sectorial Operational Program Human Resources Development 2007-2013 and by the strategic grant POSDRU/ ID 159/1.5/S/133391, "Excellence doctoral and postdoctoral programs for forming high qualified human resources for research in the fields of Life Sciences, Environment and Earth".

\section{Disclosure}

There is no conflict of interests to be declared.

\section{References}

1. Liu D. Identification, subtyping and virulence determination of Listeria monocytogenes, an important foodborne pathogen. J Med Microbiol. 2006 June;55(6):6459. DOI: 10.1099/jmm.0.46495-0

2. Low JC, Donachie W A review of Listeria monocytogenes and listeriosis. Vet J. 1997 Jan; 153(1):9-29. DOI: $10.1016 / \mathrm{S} 1090-0233(97) 80005-6$

3. Liu D, Lawrence M, Austin FW, Ainsworth AJ. Comparative assessment of acid, alkali and salt tolerance in Listeria monocytogenes virulent and avirulent strains. FEMS Microbiol Lett. 2005 Feb;243(2):373-8. DOI: 10.1016/j.femsle.2004.12.025

4. Sleator RD, Gahan CGM, Hill CA. postgenomic appraisal of osmotolerance in Listeria monocytogenes. Appl Environ Microbiol. 2003 Jan;69(1):1-9. DOI: 10.1128/AEM.69.1.1-9.2003

5. Vazquez-Boland JA, Kuhn M, Berche, P, Chakraborty, T, Dominguez-Bernal G, Goebel W, et al. Listeria pathogenesis and molecular virulence determinants. Clin Microbiol Rev. 2001 July; 14(3):584-640. DOI: 10.1128/CMR.14.3.584-640.2001

6. Charpentier E, Courvalin P. Antibiotic resistance in Listeria spp. Antimicrob Agents Chemother. 1999 Sept;43(9):2103-8.

7. Altuntas EG, Kocan D, Cosansu E, Ayhan K, Juneja 
VK, Materon L. Antibiotic and bacteriocin sensitivity of Listeria monocytogenes strains isolated from different foods. JFNS. 2012 Mar;3(3):363-8. DOI: 10.4236/ fns.2012.33052

8. Lotfollahi L, Nowrouzi J, Irajian G, Masjedian F, Kazemi B, Eslamian L, et al. Prevalence and antimicrobial resistance profiles of Listeria monocytogenes in spontaneous abortions in humans. Afr J Microbiol Res. 2011 July;5(14):1990-3. DOI: 10.5897/AJMR11.498

9. Yücel N, Çitak S, Önder M. Prevalence and antibiotic resistance of Listeria species in meat products in Ankara, Turkey. Food Microbiol. 2005 Apr;22(2):241-5. DOI: $10.1016 /$ j.fm.2004.03.007

10. SR EN ISO 11290-1, Microbiology of food and animal feeding stuffs - Horizontal method for the detection and enumeration of Listeria monocytogenes - Part 1: Detection method. 2000.

11. SR EN ISO 11290-2, Microbiology of food and animal feeding stuffs - Horizontal method for the detection and enumeration of Listeria monocytogenes - Part 2: Enumeration method. 2000.

12. SR EN ISO 11290-2/A1, Microbiology of food and animal feeding stuffs - Horizontal method for the detection and enumeration of Listeria monocytogenes - Part 2: Enumeration method, Amendament 1: Modification of the enumeration medium. 2005.

13. Clinical and Laboratory Standards Institute (CLSI), Performance standards for antimicrobial susceptibility testing; sixteenth informational supplement, NCCLS document M100-S16, CLSI. 2006;26(3):44-55.

14. Carp-Cărare C, Vlad-Sabie A, Floriştean CV. Detection and serotyping of Listeria monocytogenes in some food products from North-East of Romania. Rev Romana Med Lab. 2013 Sep;21(3):285-92. DOI: 10.2478/rrlm2013-0025

15. Gelbičova T, Karpiškova R. Outdoor environment as a source of Listeria monocytogenes in food chain. Czech J Food Sci. 2012;30(1):83-8.

16. Rahimi E, Momtaz H, Sharifzadeh A, Bezhadnia A, Ashtari MS, Esfahani SZ, et al. Prevalence and antimicrobial resistance of Listeria monocytogenes species isolated from traditional dairy products in Chahar Mahal and Bakhtiyari, Iran. Bulg J Vet Med. 2012 June; 15(2):115-22.

17. De Nes F, Riboldi GP, Frazzon APG, D'azevedo PA, Frazzon J. Antimicrobial resistance and investigation of the molecular epidemiology of Listeria monocytogenes in dairy products. Rev Soc Bras Med Trop. 2010 July/Aug;43(4):382-5. DOI: 10.1590/S003786822010000400009

18. Wang F, Chrn M, Li C, Yan M, Hsieh Y. Prevalence and antibiotic resistance of Listeria species in food products in Taipei, Taiwan. Afr J Microbiol Res. 2012 June;6(22):4702-6.

19. Ennaji H, Timinouni M, Ennaji M, Hassar M, Cohen N. Characterization and antibiotic susceptibility of Listeria monocytogenes isolated from poultry and red meat in Marocco. Infect Drug Resist. 2008 Sep;1:45-50.

20. Krawczyk-Balska A, Marchlewicz J, Dudek D, Wasiak $\mathrm{K}$, Samluk A. Identification of a ferritin-like protein of Listeria monocytogenes as a mediator of $\beta$-lactam tolerance and innate resistance to cephalosporins. BMC Microbiol. 2012 Nov;12:278. DOI: 10.1186/14712180-12-278

21. Kovacevic J, Sagert J, Wozniak A, Gilmour MW, Allen KJ. Antimicrobial resistance and co-selection phenomenon in Listeria spp. recovered from food and food production environments. Food Microbiol. 2013 Jun;34(2):319-27. DOI: 10.1016/j.fm.2013.01.002

22. Bertsch D, Muelli M, Weller M, Uruty A, Lacroix C, Meile L. Antimicrobial susceptibility and antibiotic resistance gene transfer analysis of foodborne, clinical, and environmental Listeria spp. isolates including Listeria monocytogenes. Microbiologyopen. 2014 Jan;[Epub ahead of print].

23. Korsak D, Borek A, Daniluk S, Grabowska A, Pappelbaum K. Antimicrobial susceptibilities of Listeria monocytogenes strains isolated from food and food processing environment in Poland. Int J Food Microbiol. 2012 Sep;158(3):203-8. DOI: 10.1016/j.ijfoodmicro.2012.07.016 